\title{
Effect of Natural Pesticide Bordeux Mixture on the Production of Metabolite (EPS and Siderophore) in Some PGPBs
}

\author{
Hikmet Katircioglu $^{1 *}$, Sema Çetin ${ }^{2}$ and Dürdane Kaya ${ }^{2}$ \\ ${ }^{I}$ Department of Biology Education, Faculty of Education, Gazi University, \\ Teknikokullar-Ankara, Turkey \\ ${ }^{2}$ Department of Biology, Faculty of Arts and Sciences, Kırıkkale University, \\ Yahşihan-Kirıkkkale, Turkey \\ *Corresponding author
}

\section{Keywords}

Natural pesticides, Microbial flora, Metabolic activity, EPS, Siderophore

Article Info

Accepted:

12 December 2018

Available Online:

10 January 2019

\section{A B S T R A C T}

There are many researches on the role of pesticides used in agricultural applications in the ecosystem. However, detailed research on microbial flora, especially for metabolic activity products, has not been found. Therefore, in our study the effect on microbial flora of natural pesticide, bordeux mixture used in the control of plant harmful and diseases in agricultural applications was evaluated in terms of production of EPS and siderophore. By now, looking at the studies on the effects of pesticides on the microbial flora, it was seen that they are generally evaluated in terms of bacterial inhibition, but studies on the effects of these substances on microbial metabolism have been found to be incomplete. According to the data obtained from this study, it was determined that the bordeux mixture application on the isolated strains from agricultural lands reduced EPS production efficiency (53.2-61.16\% in Bacillus cereus DY6 and 47.09 - 86.58\% in Bacillus tequilensis DT2) and increased siderophore production. As it is known, while synthetic pesticides have a destructive effect on microbial flora, due to the stress conditions it creates, natural pesticide applications can also make a high rate of change in the bacterial useful metabolic products for agriculture.

\section{Introduction}

Soil flora is heavily microorganism population and the majority of them constitute bacteria. Therefore, most of the physicochemical activities in the soil occur due to bacteria. In particular, there is plant growth promoting bacteria (PGPB) that encourage plant growth with direct and indirect effect mechanisms in the soil. The most important features of PGPB;

-can bind free nitrogen in the atmosphere, -can solve organic phosphorus, -can produce some secondary metabolites (plant hormone, siderophore and antibiotics, etc.),

-can increase systemic resistance in plants, 
-can suppress the disease with the race of place and food.

Iron chelate siderofor, which is located in the antagonist mechanism of PGPB, both deprives the pathogen from this element by binding iron and facilitates the use of iron in the plant. All organisms need iron, one of the most abundant chemical elements in the world, to use it in biological processes and to maintain cellular life. Although it is very difficult to dissolve iron by eukaryotic organisms, bacteria have developed different strategies when using iron that is necessary for them. Siderophores make complex iron elements apart from bacterium dissolve and take into the cell by active transport (Kraemer, 2004). In addition that it has been reported in various studies, siderophores produced by bacteria has effects on plant pathogens (Vessey, 2003). For example, it has been determined that siderophores produced by Pseudomonas $s p$. prevent the formation of spores of fungal pathogens and eliminate disease, pathogens such as Fusarium oxysporum and Pythium maximum which cause wilting and root rot prevented the reproduction (Sahu and Sindhu, 2011). At the same time, it has been reported that siderophores protect microorganisms from toxic effects of metals by linking metals such as aluminum, galium, chromium, copper, zinc, lead, manganese, cadmium with low affinity (Neilands, 1981; Miller, 2008; Cornelis and Andrews, 2010).

Because of these characteristics, siderophores produced by existing soil microorganisms are important in making contaminated land by suitable industrial resources for agriculture and in the biological struggle against some plant pathogens (Cornelis and Matthijs, 2007, Couillerot et al., 2009).

Another metabolite is exopolysaccharide (EPS) produced by soil microbiota and PGPBs. EPS has great importance in the interaction between the microorganism and the environment. (Kumar and Prasad, 1995; Ogut, 2009).

Bacterial EPS has a protective effect against bacteria drying, phagocytosis, phage attack, toxic components and osmotic stress and contribute to cell recognition, surface adhesion and biofilm formation in various ecosystems. EPS-producing soil microbiota and plant growth-promoting rhizobacteria can significantly enhance the volume of soil macropores and the rhizosphere aggregation, it results in increased water and fertility to inoculated plants. With the research in recent years by attention to the environmental impact of EPS produced by Pseudomonas sp., the cleaning of dirty areas, bioemulsion activity and effect of bioremediation are emphasized. Thanks to PGPB producing EPS and soil bacteria, cations such as $\mathrm{Na}^{+}$can relieve salt stress in growing plants in salty environments by connecting to EPS.

By realizing long-term damage caused by the chemicals used to increase quality and yield in agricultural production, natural pesticides were included in order to minimize the input of synthetics under the headings of "Organic Agriculture", "Integrated Struggle" and "Good Agricultural Practices". Researches on the role of pesticides used in these applications in the ecosystem are very limited. In particular, it has not been found detailed research on the metabolic activity products of microbial flora. Therefore, the effect of bordeaux mixture that is natural pesticides used in the control of plant harmful and diseases in agricultural applications on microbial flora was evaluated in terms of EPS and siderophore production. The pesticides are generally evaluated in terms of bacterial inhibition in the studies conducted until now on the topic of the effect of pesticides on the flora, but studies on the effects of these substances on microbial metabolism have been found to be incomplete. 


\section{Materials and Methods}

\section{Isolation and identification of bacteria from microbial flora}

Leaf and soil samples used in the study nonapplied the agricultural pesticide is provided from 2 station (Station 1:Demirısı Village, Station 2: Kuyuluk Region) specified as an agricultural land in Mersin. In designated stations the soil collected from $5 \mathrm{~cm}$ depth of selected parcels as 100/100 $\mathrm{cm}$ and leaves collected from trees in the region were brought to the laboratory under sterile conditions. Prepared 10 gram dilue soil and leaf samples were incubated in plates containing the nutrient agar and enrichment media. The isolations were carried out from the colonies formed as a result of incubation. In this way total 50 bacteria isolation was carried out from soil and leaf samples collected from agricultural land. Gram staining, spore staining, colony morphology and mobility have been investigated for determination of physiological and biochemical properties of isolated pure cultures. Primarily DNA isolation and sequence analysis were reviewed from samples given as pure for molecular identification. According to the the base sequence analysis of the 16S rRNA, gene region replicated with $16 \mathrm{~S}$ rDNA PCR method was conducted in Gazi University Life Sciences Application and Research Center. In our study, Bacillus cereus DY6 (leaf isolate) and Bacillus tequilensis DT2 (soil isolate) strains were selected as an indicator for metabolic activity determinations. In the determination of strains, leaf and soil samples were taken from the same stations.

\section{Natural pesticide}

Bordeaux mixture is a protective drug that contains copper ions, the main toxic agents against pathogens, used to remove the phytotoxic effect by neutralizing the $\mathrm{pH}$ of acidic copper by adding lime. In our study, Bordeaux mixture was preferred because of the widespread use in organic farming practices in our country and in the world. Properties of Bordeaux mixture used;

Product group: Fungicide

Manufacturer: Lenafruit 20 WP

Active ingredient: Calcium hydroxide and Copper (II) sulfate

Land dose: $15 \mathrm{mg} / \mathrm{ml}$

High dose: $240 \mathrm{mg} / \mathrm{ml}$

\section{Exopolysacccaride (EPS) production}

The amount of EPS was determined according to the method of Cerantola and his colleagues (Cerantola et al., 2000) Cells were boiled for 15 minutes and $1.7 \mu 1 \mathrm{TCA}$ was added to the ependorf.. The cells were removed with centrifuge for 30 minutes at $10,000 \mathrm{rpm}$ at 4 ${ }^{\circ} \mathrm{C}$, and supernatants were kept in $95 \%$ ethanol for 24 hours $\left(4{ }^{0} \mathrm{C}\right)$. After centrifuge, ethanol was removed and pellets were dissolved in distilled water. In this process, the ethanol stage is repeated by centrifuging the collapsed EPS. The EPS standard (Torino et al., 2001), determined according to phenolsulphyricacid method (Dubois et al., 1956) based on different glucose concentrations. EPS values were measured at $490 \mathrm{~nm}$.

\section{Siderophore production}

Two methods were used in siderophore production.

\section{CAS agar test}

The strains selected for monitoring siderophore production were transferred to 
Luria Broth media and incubated at $37^{\circ} \mathrm{C}$. The active strains were transferred to Chorome Azurole S agar medium with the technique of spreading with sowing and drilling with toothpast and incubated at $37{ }^{\circ} \mathrm{C}$ for 7 days. The expansion of orange rings around bacterial colonies proving siderophore production has been evaluated as data. All analyses were performed in three iterations.

\section{CAS liquid test}

In order to determine the production of siderophore by CAS liquid test, bacteria were activated in the MM9 liquid medium without iron. The culture transferred to fresh MM9 liquid media $\left(\mathrm{KH}_{2} \mathrm{PO}_{4}, \mathrm{NaCl}, \mathrm{NH}_{4} \mathrm{Cl}, \mathrm{dH}_{2} \mathrm{O}\right.$, $\mathrm{NaOH}$, Casaminoasit, Glucose, $\mathrm{MgCl}_{2}, \mathrm{CaCl}_{2}$ ) at $1 / 100$ was incubated at $37^{\circ} \mathrm{C}$.

Since siderophores are molecules secreted outside the cell, bacterial cultures were centrifuged at $10.000 \mathrm{rpm}$ at $20{ }^{\circ} \mathrm{C}$ for 5 minutes at the end of the incubation and supernatant was obtained by providing the cell pellet to collapse. For each bacterial culture, $0.5 \mathrm{ml}$ supernatant mixed with $0.5 \mathrm{ml}$ CAS solution, followed by added $10 \mu \mathrm{M}$ shuttle solution (sulphosalicilic acid, $\mathrm{dH}_{2} \mathrm{O}$ ) to strengthen the bond between CAS solution with siderophore and to clarify color change. It has been waited for at least 5 minutes for color change to occur. For spectrophotometric measurement, the culture-free MM9 medium was used as blind and the color variation in the samples were evaluated by measuring at $630 \mathrm{~nm}$ wavelength. All analyses were performed in three replications for each culture. As in CAS agar analysis, siderophore, which is secreted from the bacteria, released the dye by binding to iron and turned the color of the media from blue to orange. The following formulation was used to determine the production percentages of siderophores secreted by indicator strains used in the study quantitatively,
Siderophore's general percent account;

$\%$ Siderophore $=$ Ar-As $\times 100$

$\mathrm{Ar}$

Ar: Reference value $\left(\mathrm{A}_{630}\right)$ - (CAS solution)

As: Sample value $\left(\mathrm{A}_{630}\right)$

\section{Determination of siderophore type}

O-CAS test was carried out to determine that siderofor type by producing bacterial strain (Perez-Miranda et al., 2007). CAS medium was prepared although only as a means to reveal changes, without the presence of nutrients (Schwyn and Neilands, 1987). The medium for a liter of overlay was as follows: Chrome azurol S (CAS) $60.5 \mathrm{mg}$, hexadecyltrimetyl ammonium bromide (HDTMA) 72.9 mg, Piperazine-1,4-bis(2ethanesulfonic acid) (PIPES) $30.24 \mathrm{~g}$, and 1 $\mathrm{mMFeCl}_{3} \cdot 6 \mathrm{H}_{2} \mathrm{O}$ in $10 \mathrm{mM} 10 \mathrm{~mL} \mathrm{HCl}$. Agarose $(0.9 \%, w / v)$ was used as gelling agent. O-CAS medium prepared for the determination of the siderofor type produced was poured $20 \mathrm{ml}$ into each petri dishes and the microorganisms will be tested were applied on plates. After a maximum period of 15 min, a change in color will be observed in the overlaid medium, exclusively surrounding producer microorganisms, from blue to purple (as described in the traditional CAS assay for siderophores of the catechol type) or from blue to orange (as reported for microorganisms that produce hydroxamate type). Plates lacking microorganisms were used as negative controls at this point. All these experiments were made at least three times with three replicates for each one.

\section{Results and Discussion}

\section{Identification of isolates obtained from soil and leaf}

It was performed that biochemical tests of 8 isolates which we collected soil and leaf 
samples from 2 stations and obtained data are shown in Table 1.

Primarily, DNA isolation and sequence analysis are reviewed from samples given as pure for molecular identification. According to the base sequence analysis of the 16S rRNA, gene region replicated with $16 \mathrm{~S}$ rDNA PCR method was conducted in Gazi University Life Sciences Application and Research Center.

Soil is a good development environment for the proliferation of microorganisms and their continued existence. These microorganisms play a major role in the chemical-physical properties and productivity of the soil (Haktanır and Arcak, 1997). Genus that are found in large numbers in the soil and created 90\% of bacterial population; Pseudomonas $s p$, Arthrobacter sp, Clostridium sp, Achromabacter sp, Bacillus sp, Micrococcus sp, Flavobacterium sp. and Cellulosimicrobium sp. was found in contaminated soil through rhizosphere colonization (Chatterjee et al., 2009).

It is specified that one gram of fertile agricultural soil contains 2.5 million bacteria, 400.000 mushrooms, 50.000 algae and 30.000 protozoa (Y1ldırım, 2008). Elements such as carbon, nitrogen, phosphorus, sulphur, iron, magnesium that plants need, are turned into beneficial state in plants as a result of metabolic activities of microorganisms. Generally, the leaves of plants don't contain microorganisms when they first formed. However, different microorganisms come to the surface of the leaves in time and they live there. Leaf surface microflora is affected by many factors as type of host, structure of leaf, state of maturity and density of vegetation cover. Microorganisms that develop in the above-ground parts of plants such as leaves, branches and fruit, called epifitic microorganisms, heterotrophic and photosynthetic bacteria, yeasts, lichens and some algae are present in this group of microorganisms. Some of these microorganisms that form pigments are plant pathogens (Kaya, 2016).

Bacillus cereus DY6 (leaf isolate) and Bacillus tequilensis DT2 (soil isolate) that is obtained strains in our study were selected as indicators for metabolic activity determinations. It has been noted that leaf and soil samples are from the same station when strains are identified.

\section{Production of exopolysaccharide (EPS)}

The standard was prepared for the determination of EPS production of strains using 5-100 mg /L glucose concentrations. EPS production of strains was calculated in mg /L compared with the standard curve. The EPS production before and after the incubation with bordeaux mixture (natural pesticide) and $\%$ changing rates in strains are given in Table 2.

According to the data obtained from our study, EPS production in indicator strains was found to be $8.42 \mathrm{mg} / \mathrm{L}$ in B. cereus DY6 and 11,70 $\mathrm{mg} / \mathrm{L}$ in B. tequilensis DT2. After application of bordeaux mixture (natural pesticide) the reduction of EPS production was determined that $46.79 \%$ for Bacillus cereus DY6 MIC and $38.83 \%$ for high dose, $52.90 \%$ for Bacillus tequilensis DT2 MIC and $13.41 \%$ for high dose.

The EPS-producing mesophilic species include Bacillus spp., Lactobacillus bulgaricus, L. helveticus, L. brevis, Lactococcus lactis, Leuconostoc mesenteroides ve Streptococcus spp. (Kumar, 2012). It has been reported that the EPS produced by Bacillus spp. strain is highly viscous and pseudoplastic in a study. EPS produced by some Bacillus sp. species has features such as emulsifier, heavy metal 
cleaning capacity, pharmacological activity (Fang et al., 2013). The EPS secreted from bacteria might plays a potential role in improvement of agricultural productivity, which is yet unexplored. EPS secreted from bacteria plays a key role in encystment of artificial seeds, which protects against desiccation and predation by the protozoon's. (Looijesteijn et al., 2001), phage attack (Sutherland et al., 1994), and also affect the penetration of antimicrobial agents (Costerton et al., 1987) and toxic metals (Aleem et al., 2003). However, its application in agriculture with respect to its role in plant growth and activity is less explored. The EPS secreted from bacteria has shown enormous effect on various soil properties and plant productivity: salt tolerance, pesticide/ insecticide tolerance, soil aggregation, resistant to antimicrobial agent, vb. EPS possess unique water holding and cementing properties. Therefore, it plays a vital role in the formation and stabilization of soil aggregates and regulation of nutrients and water flow across plant roots through biofilm formation (Roberson and Firestone, 1992; Tisdall and Oadea, 1982). Moreover, it helps to increase the uptake of nutrients by plant and brings subsequent increase in plant's growth. Similarly, EPS protects nitrogenase against high $\mathrm{O}_{2}$ concentration, and participates in bacteria interaction with plants (Leigh and Coplin, 1992; Mandal et al., 2008). Bacterial EPS bind the $\mathrm{Na}^{+}$ion in the root, through which the plant's $\mathrm{Na}^{+}$accumulation decreases (Ashraf, 2004). In that way, bacteria help to alleviate salt stress in plants. It is reported that EPS produced by PGPB exhibit increased plant resistance to water stress (Sandhya et al., 2009).

\section{Siderophore production}

CAS agar test was first applied to determine siderophor production capacities. According to the findings obtained (Table 3), before treatment with bordeux mixture siderophor production was observed in only $B$. cereus DY6 but it was determined that B. cereus DY6 could not produce siderophore after treatment. In addition that Cas Liquid Test was also applied to verify the siderophor production capacities.

When the liquid test results for confirmation were examined, siderophor production was detected in both $B$. tequilensis DT2 and $B$. cereus DY6 strains, unlike the agar test. For this reason, the results that appear to be negative because of insufficient substance diffusion in the agar tests are expected to be positive in the liquid test results.

Generally increase in siderophor production was observed in liquid tests performed after pesticide application. The siderophores have the ability to solve various environmental problems such as heavy metal accumulation, paint removal and cleaning of sewage water. In addition, chemical compounds produced by microorganisms around the plant roots (in the rhizosphere) increase the availability and uptake of certain essential minerals such as iron. It has been determined that siderophores produced by bacteria are also effective on plant pathogens (Vessey, 2003). It has been reported that the siderophores can be used especially in agricultural applications, in soils that are industrially contaminated and salty caused by biological fighting (Cornelis and Matthijs, 2007, Couillerot et al., 2009). The increase in secondary metabolite siderophores, produced by bacteria in the stress conditions after the agricultural struggle practices, is an indication of the stress in the current ecosystem (Couillerot et al., 2009).

The major issues in production of soil microorganisms or biofertilizers (PGPB) have the characteristics of high rate of dinitrogen fixation, wide range of antagonistic activity towards phytopathogens, the ability to produce EPS, siderophores, vitamins and growth 
factors in agricultural prospective (Kravchenko et al., 2002).

\section{Siderophore production scales}

Strains that were not treated with pesticide were used as positive controls for siderophore production percentages of B. cereus DY6 and B. tequilensis DT2 strains selected as indicator strains for CAS Liquid Test. The values in the samples which have siderophor production should be lower than the reference values (Payne, 1994). The color loss in samples and reference (uninoculated $0.5 \mathrm{ml}$ MM9 medium $+0.5 \mathrm{ml}$ CAS solution +10 micromolar shuttle solution) were determined by measuring at $630 \mathrm{~nm}$ wavelength. The readings were made by using the reference tube as blind and reset. Accordingly, the changes in $\%$ the siderophor production capacities of indicator B. cereus DY6 and $B$. tequilensis DT2 strains were also calculated and given in Figure 1.

According to this, the siderophore production rate of B. cereus DY6 strains isolated from agricultural soil was found to be $92.3 \%$ in our study whereas siderophore production was found to be $22.3 \%$ in Bacillus cereus DSM 4312 bacterial isolate from sea (Güney, 2014). It is determined that the percentage of siderophore production in the strains were decreased after the incubation of bordeaux mixture with the dose used in field applications (MIC). This result is the first finding of natural pesticide (bordeaux mixture) applications, which is considered as an environmental factor in the production of siderophores.

Table.1 Morphological, cultural and molecular characteristics of bacterial strains isolated from soil and leaf samples (DY, Leaf isolate; DT, Soil isolate; S1, Station 1; S2, Station 2)

\begin{tabular}{|l|l|l|l|l|l|l|l|l|}
\hline $\begin{array}{l}\text { Isolate } \\
\text { Code }\end{array}$ & $\begin{array}{l}\text { Isolation } \\
\text { Place }\end{array}$ & $\begin{array}{l}\text { Station } \\
\text { Name }\end{array}$ & $\begin{array}{l}\text { Colony } \\
\text { Color }\end{array}$ & $\begin{array}{l}\text { Colony } \\
\text { Morphology }\end{array}$ & $\begin{array}{l}\text { Cell } \\
\text { Form }\end{array}$ & $\begin{array}{l}\text { Spore } \\
\text { Painting }\end{array}$ & $\begin{array}{l}\text { EMBL/Gen } \\
\text { Bank } \\
\text { Number }\end{array}$ & $\begin{array}{l}\text { Name of the } \\
\text { Species }\end{array}$ \\
\hline DY1 & S1 Leaf & Station A & White & R Type & Bacil & + & KT720227.1 & B. invictae \\
\hline DY2 & S2 Leaf & Station B & White & R Type & Bacil & + & KJ801578.1 & B. cereus \\
\hline DY3 & S1 Leaf & Station A & White & R Type & Bacil & + & HQ678662.1 & B. subtilis \\
\hline DY4 & S2 Leaf & Station B & Yellow & S Type & Coccus & - & KC117526.1 & $\begin{array}{l}\text { Cellulosimicro } \\
\text { bium sp. }\end{array}$ \\
\hline DY5 & S1 Leaf & Station A & White & R Type & Bacil & + & KT720017.1 & B. subtilis \\
\hline DY6 & S1 Leaf & Station A & White & R Type & Bacil & + & KT719870.1 & B. cereus \\
\hline DT1 & S1 Soil & Station A & Yellow & S Type & Coccus & - & KT719656.1 & $\begin{array}{l}\text { Micrococcus } \\
\text { yunnanensis }\end{array}$ \\
\hline DT2 & S1 Soil & Station A & White & R Type & Bacil & + & KT720350.1 & B. tequilensis \\
\hline
\end{tabular}

Table.2 EPS production volume changes in strains after incubation with bordeaux mixture (natural pesticide)

\begin{tabular}{|l|c|c|c|c|}
\hline $\begin{array}{l}\text { Bordeaux mixture } \\
\text { Concentration }\end{array}$ & $\begin{array}{l}\text { B. cereus DY6 } \\
\text { EPS }(\mathbf{m g} / \mathrm{L})\end{array}$ & $\begin{array}{l}\text { B. tequilensis DT2 } \\
\text { EPS }(\mathbf{m g} / \mathbf{L})\end{array}$ & $\begin{array}{l}\text { B. cereus DY6 } \\
\text { \% change }\end{array}$ & $\begin{array}{l}\text { B. tequilensis DT2 } \\
\text { \% change }\end{array}$ \\
\hline Control & $8.42 \pm 0,01$ & $11.70 \pm 0,01$ & - & - \\
\hline MIC $(15 \mathrm{mg} / \mathrm{ml})$ & $4.48 \pm 0,01$ & $5.51 \pm 0,01$ & 53.2 & 47.09 \\
\hline High dose $(240 \mathrm{mg} / \mathrm{ml})$ & $5.15 \pm 0,01$ & $10.13 \pm 0,01$ & 61.16 & 86.58 \\
\hline
\end{tabular}


Table.3 CAS Agar and liquid test results

\begin{tabular}{|c|c|c|}
\hline Test strains & $\begin{array}{c}\text { CAS-agar test } \\
\text { drilling }\end{array}$ & $\begin{array}{c}\text { CAS- liquid test } \\
\left(\mathbf{O D}_{\mathbf{6 3 0}}\right)\end{array}$ \\
\hline B. tequilensis DT2 & - & $0,171-0,196$ \\
\hline B. tequilensis DT2 MIC & - & $0,187-0,208$ \\
\hline B. tequilensis DT2 High dose & - & $0,056-0,076$ \\
\hline B. cereus DY6 & + & 0,077 \\
\hline B. cereus DY6 MIC & - & 0,100 \\
\hline B. cereus DY6 High dose & - & 0,111 \\
\hline
\end{tabular}

Fig.1 \% siderophor production capacities and \% change rates

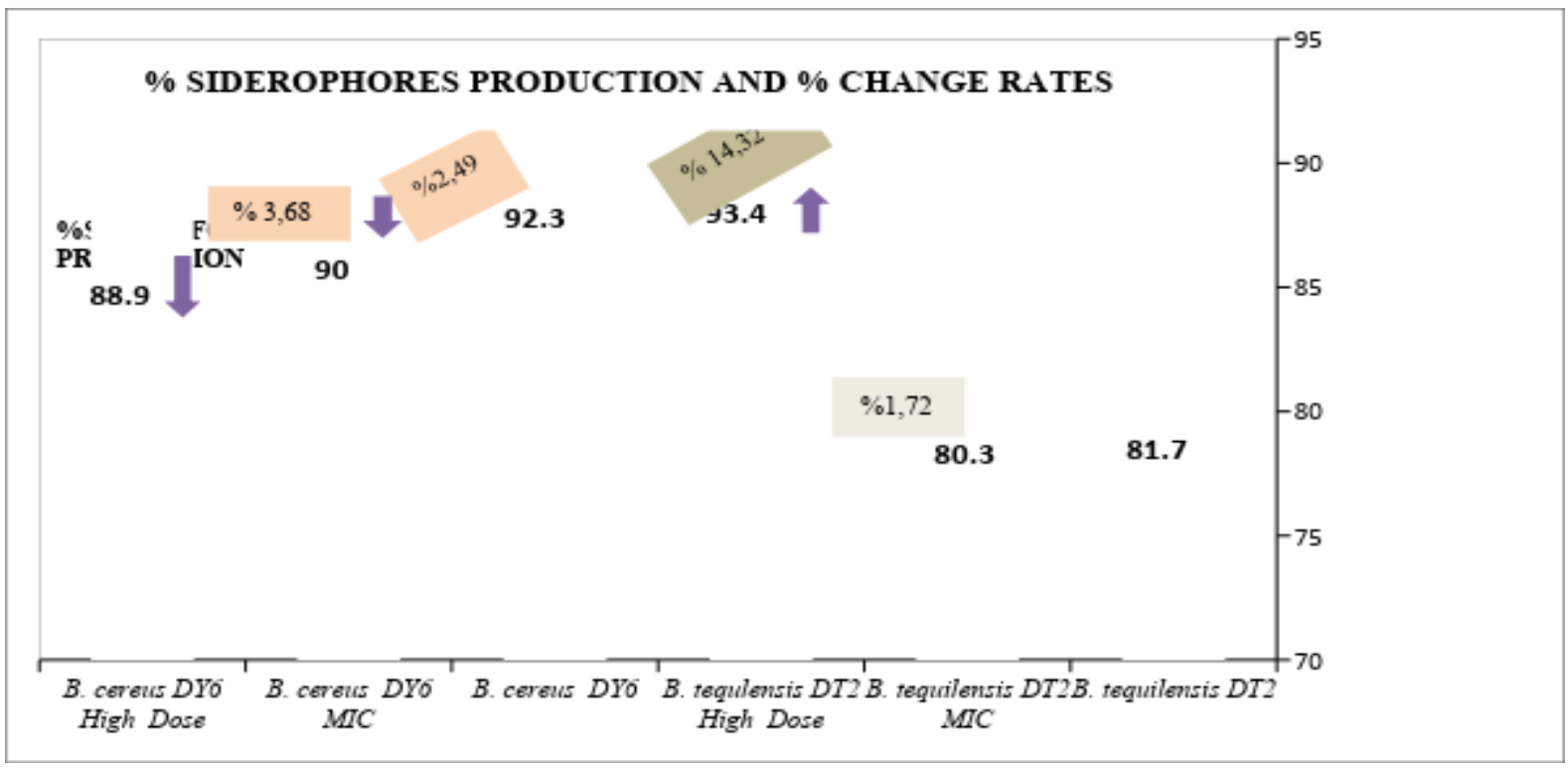

\section{Siderophor type}

The type of siderophores produced by strains isolated in our study was determined as "catecholate type". The siderophores are divided into four major groups, hydroxamate, catecholate, carboxylate and mixed ligands mainly according to chemical composition and microbial origins. The transition from the blue to the yellow-orange shows hydroxomate type and transition from the blue to the purple shows catecholate type (Pérez-Miranda et al., 2007). It is known that Bacillus species produce catechol-type siderophor from many previous studies (Williams et al., 2012; Modi et al., 2012).
In conclusion, there aren't any studies about the effects of natural pesticides on plant and soil flora until now. The naturally classified and the most common use of pesticides used in our study is bordeaux mixture. When we look at the studies conducted in relation to this subject, it was seen that studies of the effect on living things concentrate in synthetic pesticides (Bilaloğlu, 1982; Çelik, 2003; Pandey, 2008; Aydemir, 2008; Bolle, 2004; Koca, 2008; Kara,1998; Gill. and Shaukat, 2000; Ozorgucu, et al.,1995). It is realised that the literature has been found to be very limited when the studies about the effects of natural pesticides (bordeaux mixture, plant and animal fats, some plant extracts, etc.) and biopesticides (Bacillus thuringiens preparats 
etc) on microorganisms (Kotan et al., 2010; Tozlu et al., 2011). Pesticides used in agricultural warfare can cause increase in product by destroying target organisms and also cause damage to non-target organisms (MacMahon, 1994). As a result; this study is example work in terms of determining these soil microorganisms that beneficial to agriculture how affected by natural pesticides.

\section{Acknowledgements}

This work was financially supported by the Kırıkkale University Research Fund with grant number of 2015/36.

\section{References}

Aleem, A., Isar, J., Malik, A. 2003. Impact of long-term application of industrial wastewater on the emergence of resistance traits in Azotobacter chroococcum isolated from rhizosphere soil. Bioresour. Technol. 86(1): 7-13.

Ashraf, M. 2004. Photosynthetic capacity and ion accumulation in a medicinal plant henbane (Hyoscyamus niger L.) under salt stress. Journal of Applied Botany and Food Quality. 78(2): 91-96.

Aydemir, N., Çelikler, S., Sumak, Ş., Y1lmaz, D. 2008. Evaluation of clastogenicity of 4, 6-dinitro-o-cresol (DNOC) in allium root tip test. J. Biol. Environ. Sci. 2(5): 59-63.

Bolle, P., Mastrangelo, S., Tucci, S. P., Evandri, M. G. 2004. Clastogenicity of atrazine assessed with the Allium cepa test, Environmental and Molecular Mutagenesis. 43:137-141.

Bilaloğlu, R. 1982. A research on the cytological deviations that create in Allium cepa $L$. stem meristem cells of some pesticides. Ph. D. Thesis, Ege University, İzmir, Turkey.

Cerantola, S., Bovnery, J.D., Segonds, C., Marty, N., Montrozier, H., 2000. EPS production by mucoid and non-mucoid strains of B. cepacia. FEMS Microb. Let. 185: 243-246.

Chatterjee, S., Sau, G.B. and Mukherjee, S.K. 2009. Plant growth promotion by hexavalentchromium reducing bacterial strain, Cellulosimicrobium cellulans KUCr3. World J. Microbiol. Biotechnol. 25, 1829-1836.

Cornelis, P., Andrews, C. 2010. Iron uptake and homeostasis in microorganisms. National Academies Press. 978: 65-73.

Cornelis, P., Matthijs, S. 2007. Pseudomonas siderophores and their biological significance. Soil Biology \& Biochemistry. 12: 193-203.

Costerton, J.W., Cheng, K.J., Geesey, G.G., Ladd, T.I., Nickel, J.C. 1987. Bacterial biofilms in nature and disease. Annu. Rev. Microbiol. 41: 435- 464.

Couillerot, O., Prigent-Combaret, C., Caballero-Mellado, J., Moënne-Loccoz, Y. 2009. Pseudomonas fluorescens and closely-related fluorescent Pseudomonads as biocontrol agents of soil-borne phytopathogens. Letters in Applied Microbiology. 48, 505-512.

Çelik, M. 2003. The cytogenetic effects of Dinocap fungicide on Allium cepa L. stem cells and human peripheral lymphocytes. Ph.D. Thesis, Gazi University, Ankara, Turkey.

Dubois, M., Gilles, C.A., Hamilton, J.K., Rebers, P.A., Smith, F. 1956. Colorimetric method for determination of sugars and related substances. Anal. Chem. 28, 350-356.

Fang, Y., Ahmed, S., Liu, S., Wang, S., Lu, M., Jiao, Y. 2013. Optimization of antioxidant exopolysaccharides production by Bacillus licheniformis in solid state fermentation. Carbohyd. Polym. 98, 1377-1382.

Gill, S. A., Shaukat, S. S. 2000. Genotoxic effects of Captan fungicide on root meristems of Allium cepa L. in vivo. 
Pakistan Journal of Biological Sciences 3 (1): 114-117.

Güney, E. 2014. Siderophore production in Bacillus $s p$. and optimization of siderophore production in Bacillus cereus DSM 312. Master Thesis, Gebze Teknik University, Gebze, Turkey.

Haktanır, K., Arcak, S. 1997. Effects of the tillage systems on $\mathrm{CO}_{2}$ emission from Soil. Soil Biology. Ankara University Faculty of Agriculture Publication, Ankara. No: 1486.

Kara, G. 1998. Investigation of the effects of dirty water on some vegetable plants. Master Thesis, Ege University, İzmir, Turkey.

Kaya, D. 2016. The influence of pesticides (biopesticide, synthetic and natural pesticide) on microbial flora. Master Thesis, Kirikkale University, Kirikkale, Turkey.

Kravchenko, L.V., Makarova, N.M., Azarova, T.S., Provorov, N.A., Tikhonovich, I.A. 2002. Isolation and phenotypic characterization of plant growth promoting Rhizobacteria with high antiphytopathogenic activity and rootcolonizing ability. Microbiology 71(4): 444-448.

Kumar, M., Prasad, H. 1995. Cytotoxic effects of two herbicides on meiosis. Maize Genetics Cooperation Newsletter $69,25$.

Koca, S. 2008. The cytogenetic effects of Sheffer A, A Liquid fertilizer and growth regulator in root tip cells of Vicia faba L. C.B.U. Journal of Science 4 (1): 121-126.

Kotan, R., Çakmakçı, R., Şahin, F., Karagöz, K., Dadaşoğlu, F., Kantar, F. 2010. Biological struggle studies for the control of diseases and pests using bacterial biocaps in Turkey. 4. Organic Agriculture Symposium, Turkey, $\mathrm{p}$. 711-723.
Kraemer, S.M. 2004. Iron oxide dissolution and solubility in presence of siderophores. Aquatic Sciences 66, 318.

Kumar, T. 2012. Microbial extracellular polymeric substances production, isolation and Applications. IOSR J. Pharmacol. 2 (2): 276-281.

Leigh, J.A., Coplin, D.L. 1992. Exopolysaccharides in plant-bacterial interactions. Annu. Rev. Microbiol. 46, 307-346.

Looijesteijn, P.J., Trapet, L., de Vries, E., Abee, T., Hugenholtz, J. 2001. Physiological function of exopolysaccharides produced by Lactococcus lactis. Int. J. Food Microbiol. 64(1): 71-80.

MacMahon, B. 1994. Pesticide residues and breast cancer. J. Natl. Cancer Inst. 86, 572-573.

Mandal, B., Mandal, S., Csinos, A.S., Martinez, N., Culbreath, A.K. 2008. Biological and molecular analyses of the acibenzolar-S-methyl-induced systemic acquired resistance in fluecured tobacco against tomato spotted wilt virus. Phytopathology 98(2): 196204.

Miller, M. J. 2008. Siderophores (microbial iron chelators) and siderophore-drug conjugates (new methods for microbially selective drug delivery. Doctor of Philosophy Thesis, University of Notre Dame.

Modi, P., Kaur, A., Kaur, M., Kapoor, V.K. 2012. Siderophores: A novel approach for iron removal. International Journal of Universal Pharmacy and Biosciences. 2, 628-636.

Neilands, J. B. 1981. Microbial iron compounds. Annual Review of Biochemistry. 50, 715-731.

Öğüt, S., Seçilmiş, H. 2009. Potential environmental effects of pesticides. International Davraz Congress,. Turkey. 
Özörgücü, B.T., Oğuz, G., Gönüz, A., Acar, O. 1994. The effects of the underground waters of industrial zone on mitosis of Allium cepa $L$. stem cells. XII. National Biology Congress, Turkey, 52, 1-7.

Pandey, R. M. 2008. Cytotoxic Effects of Pesticides in Somatic Cells of Vicia faba L., Cytogenetics Section, Allerton Press, Inc., India., 42 (6): 373-377.

Payne, S. M. 1994. Detection, isolation and characterization of siderophores. Methods in Enzymology. 235, 329-342.

Pérez-Miranda, S., Cabirol, N., GeorgeTéllez, R., Zamudio-Rivera, L.S., Fernández, F.J. 2007. O-CAS, a fast and universal method for siderophore detection. Journal of Microbiological Methods. 70, 127-131.

Roberson, E.B., Firestone, M.K. 1992. Relationship between desiccation and exopolysaccharide production in a soil Pseudomonas sp. Appl. Environ. Microbiol. 58 (4): 1284-1291.

Sahu, G.K. and Sindhu, S.S. 2011. Disease control and plant growth promotion of green gram by siderophore producing Pseudomonas sp. Research Journal of Microbiology. 6 (10):735-749.

Sandhya, V., Ali, Sk Z., Reddy, G., Venkateswarlu, B. 2009. Alleviation of drought stress effects in sunflower seedlings by exopolysaccharides producing Pseudomonas putida strain P45. Biology and Fertility of Soils. 46(1): 17-26.

Schwyn, B. and Neilands, J.B. 1987. Universal chemical assay for the detection and determination of siderophores. Analytical Biochemistry. 160, 47-56.

Sutherland, M., Hendrik, J.J., Vuuren, V., Martha, M. 1994. Cloning, sequence and in vitro transcription/translation analysis of a 3.2-kb EcoRI-HindIII fragment of Leuconostoc oenos bacteriophage L10 gene. Gene. 148(1): 125-129.

Tisdall, J.M., Oadea, J.M. 1982. Organic matter and water stable aggregates in soils. J. Soil Sci. 33, 141-163.

Torino, M.I., Taranto, M.P., Serve, E. and de Valdec, G.E. 2001. Heterodermentative pattern and exopolysaccharides production by $L$. helveticus ATCC 15807 in response to environmental $\mathrm{pH}$. J. Appl. Microbiol. 91, 846-852.

Tozlu E., Dadaşoğlu, F., Kotan, R., Tozlu, G. 2011. Insecticidal effect of some bacteria on Bruchus dentipes Baudi (Coleoptera: Bruchidae). Fresenius Environmental Bulletin. 20 (4): 918923.

Vessey, J.K. 2003. Plant growth promoting Rhizobacteria as biofertilizers. Plant and Soil. 255, 571-586.

Williams, K. M., Martin, W. E., Smith, J., Williams, B. S., Garner, B. L., 2012. Production of protocatechuic acid in Bacillus thuringiensis ATCC33679. International Journal of Molecular Sciences, 13 (3): 3765-3772.

Yıldırım, E. 2008. Agricultural pest control methods and drugs, Atatürk University Faculty of Agriculture Publication, Erzurum, 219, p. 350.

\section{How to cite this article:}

Hikmet Katırcıoğlu, Sema Çetin and Dürdane Kaya. 2019. Effect of Natural Pesticide Bordeux Mixture on the Production of Metabolite (EPS and Siderophore) in Some PGPBs. Int.J.Curr.Microbiol.App.Sci. 8(01): 1863-1873. doi: https://doi.org/10.20546/ijcmas.2019.801.196 